Editorial

\section{Haemostasis in Times of COVID-19}

Rüdiger E. Scharf ${ }^{1}$

1 Program in Cellular and Molecular Medicine, Boston Children's Hospital,
Harvard Medical School, Boston, Massachusetts, USA

Hämostaseologie 2020;40:141.

The novel coronavirus, designated SARS-CoV-2, that was detected in Wuhan, China, has spread rapidly and globally since the end of 2019. As reported by the Johns Hopkins Coronavirus Resource Center, SARS-CoV-2 has caused worldwide more than 197,000 confirmed infections and more than 7,900 fatalities (as of March 17, 2020). ${ }^{1}$ But these numbers will be already outdated and dramatically increased when this article goes to print a few days from now. Consequently, the outbreak has been declared a pandemic by the World Health Organization on March 11, 2020. ${ }^{2}$

The impact and consequences of this global crisis on individual subjects, patients in particular, hospital staff, health care systems, social life and economy are unpredictable. However, what is quite sure for now, the world will not be the same that it was before. Except physicians, nurses and lab technicians, most of the scientists and other health care personnel will have to decelerate their unconditional professional activities. Paper work, reading and writing are the current activities, instead of traveling to and lecturing at national and international conferences, which are no longer taking place anyway in the foreseeable future.

In this context, the speakers and the attendees of the most recent Annual GTH Meeting that took place in Bremen from February 18 to 21, 2020, are keeping best memories of this exciting conference. Professor Florian Langer and Professor Thomas Renné designed a top scientific program with prominent experts and also introduced several highly appreciated novel formats to promote and foster the exchange between established scientists and young investigators or clinicians and medical practitioners.

Moreover, this year's congress presidents did a superb job in asking the invited speakers to submit a manuscript of their presentation, and most of them accepted. As mentioned in a previous editorial, ${ }^{3}$ Florian was so successful in his activities that the number of articles contributed by plenary and

keynote speakers exceeded by far the number of papers that can be printed in one edition.

I am therefore delighted that the current issue of Hämostaseologie Progress in Haemostasis presents part II of the GTH Congress 2020 and that the contributions are pub-

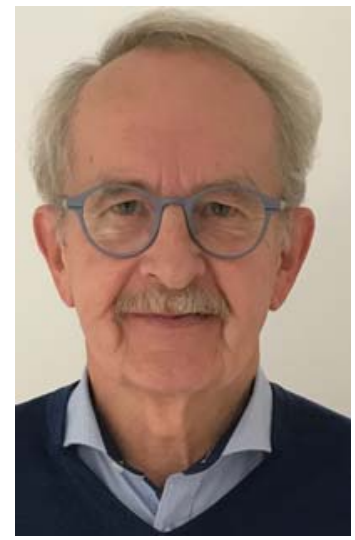

Rüdiger E. Scharf lished timely after the Bremen meeting. As in issue 1/2020 (part I), ${ }^{4}$ both guest editors introduce the selected contributions of part II, again focusing on this year's congress motto "Novel Concepts for a Lifetime Challenge". ${ }^{5}$

I trust that the current and previous issue of the Journal provide sufficient reading matter that is of major interest both to those who could attend the Bremen meeting and to those who were unable to attend. Getting inspired by reading and reflecting on research and scientific information may be one of the appropriate activities for most of the investigators in times of COVID-19. Thus, I wish you fruitful reading hours - and stay healthy.

\title{
References
}

1 Johns Hopkins Coronary Resource Center. Reported confirmed cases of COVID-19, 2020. Available at: coronavirus.jhu.edu. Accessed March 23, 2020

2 WHO. Director General's opening remarks at the media briefing on COVID-19-March 11, 2020. Available at: www.who.int. Accessed March 23, 2020

3 Scharf RE. 40 Years of hämostaseologie - progress in haemostasis. Hamostaseologie 2020;40(01):7-8

4 Langer F, Renné T. 64th Annual Congress of the Gesellschaft für Thrombose- und Hämostaseforschung e.V. in Bremen. Hamostaseologie 2020;40(01):9-11

5 Langer F, Renné T. 64th Annual Congress of the Gesellschaft für Thrombose- und Hämostaseforschung e.V. in Bremen. Novel concepts of a lifetime challenge (part II). Hamostaseologie 2020;40:143-144

(C) 2020 Georg Thieme Verlag KC Stuttgart · New York

received

March 17, 2020

accepted

March 17, 2020
DOI https://doi.org/ $10.1055 / \mathrm{a}-1081-6832$ ISSN 0720-9355.

Program in Cellular and Molecular

Karp Family Research Laboratories, 1

Blackfan Circle, RB09211.1, Boston,

MA 02115, USA

(e-mail: ruediger.scharf@

childrens.harvard.edu). 